\title{
Effects of Cittaslow Movement on Conservation of Cultural Heritage: Case of Seferihisar \& Halfeti, Turkey
}

\author{
Müjgan Karatosun, Deniz Çakar* \\ Department of Architecture, Dokuz Eylül University, Turkey
}

Copyright $(2017$ by authors, all rights reserved. Authors agree that this article remains permanently open access under the terms of the Creative Commons Attribution License 4.0 International License

\begin{abstract}
Considerations related to the definition of cultural heritage have been changed importantly in historical period. In the past, the concept of heritage was in the scope of conservation considered with its monumental value. But in time its cultural and identity value has started to be discussed. Cultural heritage has started to be considered integrated with its environment after the many ideas were established in years and the necessity of the continuation of the "cultural identity" concept has been taken importance. Cittaslow movement is an internationally recognized movement and aims to transform cities into places of high quality. The aim of this article is to evaluate the impacts of Cittaslow movement on integrative conservation of cultural heritage. Within this framework, international conservation documents are examined to follow the development process of integrative conservation of cultural heritage as a new approach. In the research, two Cittaslow settlement of Turkey named Seferihisar and Halfeti have been studied. By taking into consideration projects developed after the membership within the scope of conservation, direct and indirect effects of Cittaslow movement on conservation of cultural heritage have been revealed. The types, contents and situations of actualization of these projects have been taken into consideration as determinants.
\end{abstract}

Keywords Cittaslow Movement, Cultural Heritage, Integrated Conservation

\section{Introduction}

The development process of the concept of cultural heritage can be examined in three phases. In the first phase, the aspect of "monument" has changed from singularity into integrity and has begun to be discussed with environmental context. In the second phase, the concept of "cultural heritage" has been aroused. In the third phase, spiritual properties of heritage have been discussed except physical properties [1].
The evolution related to the meaning of cultural heritage has deeply influenced the bases of updated urban movements. In this research, Cittaslow that is an urban movement which has adopted the philosophy of "slowness" has been discussed. An important point that Miele has emphasized is that the aim of Cittaslow movement is not directly related to conservation of cultural heritage. The aim is to provide solutions to the effects of industrialization on local values in a world that is in a modernization process [2].

\section{Conservation of Cultural Heritage as a Part of International Documents}

Accurate conservation of inheritance of the humanity is possible by defining the context of cultural heritage and determining conservation methods. From this perspective, new terms and various concepts about conservation were accepted on international scale. While in the first half of the 20th century, the term of 'heritage' was used for the conservation of single scaled historic buildings; in the second half, the framework of the conservation discipline had expanded with the occurrence of the term 'cultural heritage' [3]. In this way, cultural heritage has proceeded to include different scaled built heritages and site areas integratively. It can be mentioned that current definition and methods within conservation cultural heritage, took their shapes after this expansion of meaning that has occurred at the end of the 20th century. Within this period, the concept of heritage went from single scale to an integrative approach and shifted from a tangible dimension to an intangible one (Figure 1).

Upon examining the development of terms about heritage on the international documents, it can be seen that it was expressed only as monuments and historic sites up until 1950s. However, in 1954, with the Hague Convention, it initially took its place under the term 'cultural assets'. Accordingly, the definition of cultural assets not only included monuments and historic sites but also fabric of traditional built heritage and historical squares [4]. One of 
the most efficient international charters which play an important role for the development of current conservation approach is the Venice Charter (1964), where the definition of heritage started to take place on an urban scale [5]. Another important document is UNESCO Convention Concerning the Protection of the World Cultural and Natural Heritage (1972), which defined heritage as being 'cultural heritage' and also 'natural heritage' for the first time. In this way, the definition of cultural heritage was expanded to include the physical texture and landscaping of places [6]. During this decade, the Declaration of Amsterdam (1975) was a further important document that widens perspectives by providing an integrative approach to the conservation of built cultural heritage with its environment [7].

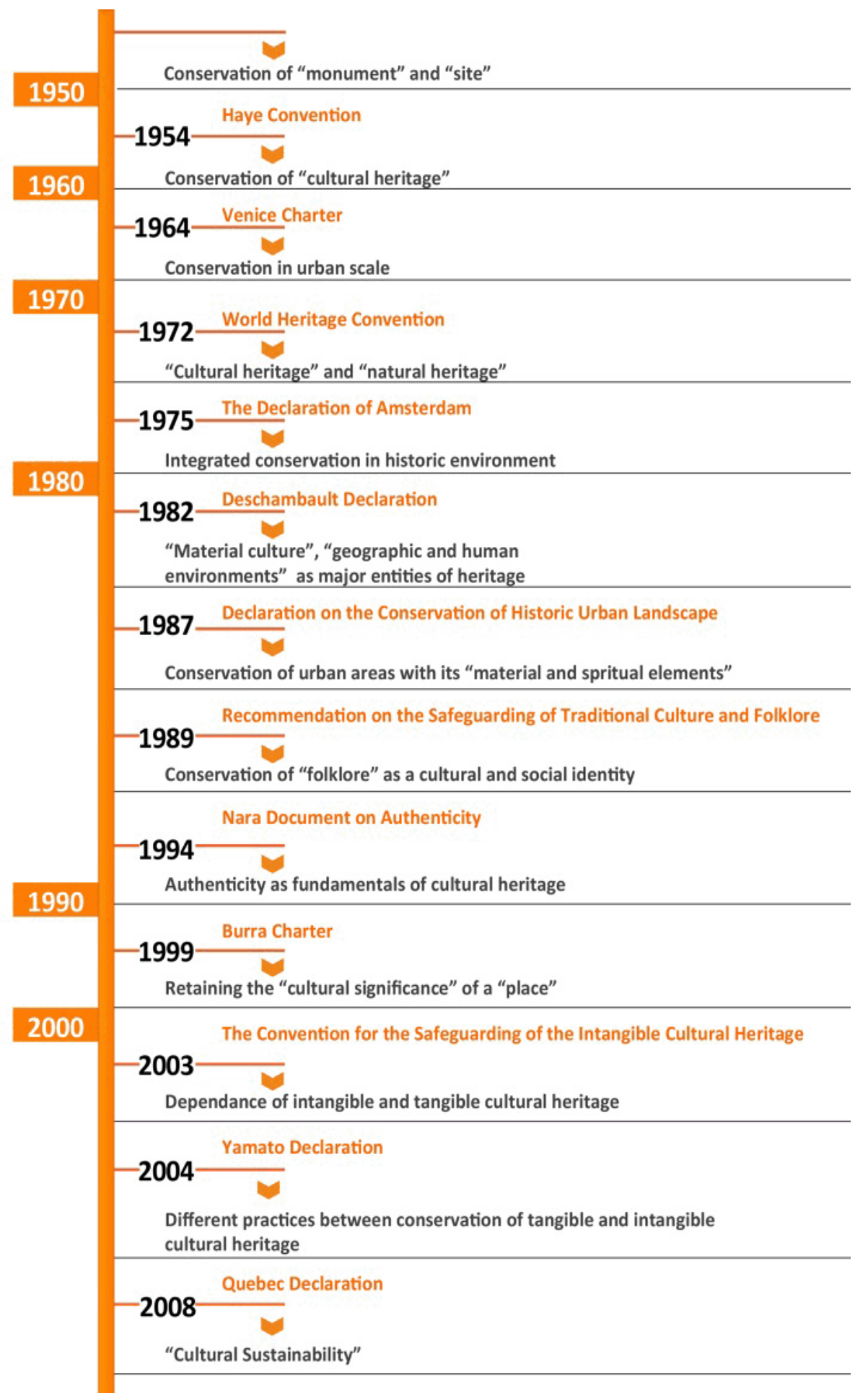

Figure 1. International conservation documents 
Referring to international documents, only the conservation of physical aspects of cultural heritage was taken into account until the 1980s. Since 1980s, cultural heritage has begun to be discussed in terms of intangible values and 'the spirit of place' and 'cultural identity' arose as new concepts. It can be said that the ICOMOS Deschambault Charter for the Preservation of Quebec's Heritage (1982) that emphasized heritage is not only related to built environment but also with geography and the human factors is the precursor document for such an approach [8]. Other documents that has mentioned the importance of locality on conservation of cultural heritage are ICOMOS Washington Charter on the conservation of Historic Towns and Urban Areas (1987), which emphasizes both substantial and spiritual dimensions of characteristics of historical urban areas [9] and UNESCO Popular and Traditional Cultural Protection Recommendation (1989), which defines the term of 'intangible cultural heritage' as the totality of tradition-based creations of a cultural community [10].

ICOMOS Nara Document on Authenticity (1994), ICOMOS the Burra Charter (1999) and UNESCO Convention for the Safeguarding of The Tangible Cultural Heritage (2003) are considerable documents in bringing integrated approach to the conservation of tangible and intangible cultural heritage. While Nara Document on Authenticity has emphasized the significance of the term 'spirit of place' as an intangible value [11], the Burra Charter has established a relation between 'locality' and 'culture' [12] and Convention for the Safeguarding of the Tangible Cultural Heritage has mentioned ways for safeguarding survival of cultural heritage [13]. Yamato Declaration (2004) brought up a new approach by pointing that there is no need for the human factor on conservation of tangible cultural heritages. However, the conservation of intangible can be achieved by the preservation of the living spaces of locals [14]. Further significant international document is ICOMOS Charter of Quebec (2008) the term 'spirit of place' was deeply examined as a matter of cultural sustainability. As the document, establishing communication between generations and cultures is important for the conservation of 'spirit of place' [15].

Nowadays, perspectives developed in description of the cultural heritage brought up the necessity of an integrated conservation of tangible and intangible values and mentioned its relation with 'place'. The outcome of this approach is the term of 'local identity'. By this way, the matter of conservation cultural heritage has been carried onto a universal platform and has become the focal point of humanity.

Despite the developments made in integrative conservation approach, which is directed towards the conservation of tangible and intangible cultural heritage, it appears as though there are factors, which threaten the continuation of identity in today's settlements. These factors can be expressed as being the creation of a global culture on earth, whereby society's lifestyles become similar and parallel to the developments in technology, which enables the speed of daily living to increase causing the worthlessness of cultural values. This situation brought along the uniformed environments, which moved further away from uniqueness and societies which focus on mass production and consumption. This loss of identity in settlements has been the subject in international documents as 'globalization' and its effects on tangible and intangible cultural heritage were mentioned therein.

As a result of the loss of cultural identity in settlements, various social movements emerged as alternative approaches. These movements brought local identity and cultural values to the forefront as against the problem of standardization. Amongst public opinion, the movement that created a great impression with its philosophy is the 'slow movement'. The 'Cittaslow' that is examined in this research, has adopted the philosophy of slow movement and purpose to bring its approaches in urban scale.

\section{Cittaslow Movement in the Context of Conservation of Cultural Heritage}

Industrialization has provided technological advances, created opportunities in communication and infused societies into fast lifestyles that enabled standardization among cultures. Although this is a necessity of our era and has many benefits, its side effects on many dimensions are also discussed. Briefly, abolishing the relation between place and action and causing the risk of extinction of local values by worldwide spread global culture can be described these side effects on conservation of cultural heritage.

The purpose of Cittaslow movement is to present a high quality life style by resisting against loss of identity which arises as a result of monotonous life styles of the societies in the globalized world and losing the identity as a result of losing cultural values. According to Honoré [16], the aim of the movement is not to act against capitalism but to add to it a human factor instead. He also defends a life balanced between 'fast' and 'slow' by changing the life style brought by modern life [16].

Slow philosophy, in which its basis is the foundation of the slow movement, was formed in Bra, Italy in 1980 as a resistance against effects of globalization. Fundamentally the philosophy of slow defends that life values and the concept of location are not separable and that they should be treated as a whole. It also supports re-increasing the importance of cultural differences and bringing localization back to the forefront. In that, localization is only meaningful when it is sustainable and is lived in its own environment [17]. It is understood that the perspective of the strong relation between 'place' and 'culture', which was emphasized by the international documents after 1980 's, also has impact on slow philosophy.

Cittaslow is a local administration approach that has arisen because settlements lost their cultures, natural values come under risk and the quality of life decreased as results of 
industrialization and fast life style. As Dogrusoy and Dalgakıran [17] have indicated, main objectives of the movement is to take the slow philosophy as the basis and strengthen the relationship between society and the urban environment, conserve local values, improve cultural and social potential and to pass it on to future generations [17].

In this research, effects of Cittaslow movement, in regards to the conservation of cultural heritage, which provides an integrative approach, through the slow towns of Seferihisar and Halfeti which are located in Turkey. Due to the lack of policies regarding to the conservation of cultural heritages, many problems have arisen; such as irregularities in social and economic policies, decisions of urban planning that has destructive effects on historical environments, society's unawareness, lack of inspection in the application of conservation projects, unlawful benefits from lands and receiving insufficient funds in the budget for the conservation of historical values. From this point of view, it is important to examine effects of a new urban movement to conservation in Turkey. In 2009, firstly Seferihisar has assumed the title of Cittaslow and in following years ten more towns have joined in this collaboration. These towns are as follows; Tarakli (Sakarya), Yalvaç (Isparta), Vize (Kirklareli), Gökçeada (Çanakkale), Yenipazar (Aydın), Halfeti (Şanliurfa), Akyaka (Muğla), Perşembe (Ordu), Şavsat (Artvin) ve Uzundere (Erzurum) [18] (Figure 2).
The reasons for examining two different cities in comparison are that the conservation states of cultural heritages are different and projects developed under the Cittaslow are in various aspects. The municipality of Seferihisar, aside from improvement of historical pattern of the city aimed to increase the trade-mark value of the city by revitalizing the local products and traditions. On the other hand, Halfeti is trying to make a name for itself by using Cittaslow and devising projects with which the tangible cultural heritage underwater can be rescued and revitalize the city once again.

Conservation based projects that are developed in Seferihisar and Halfeti (Figure 2) within the scope of the membership to Cittaslow movement, were examined separately under the headings of tangible and intangible cultural heritage. In this regards, projects of conservation tangible cultural heritage are examined under fabric (group of building or site) and building scales. On the other hand, projects of conservation intangible cultural heritage are handled under social practices, local products and traditional handcrafts. As a result of the examination of the effects of all of the conservation projects, examinations under this classification, on the identity of the city, the effects of a total approach in conservation of cultural heritage could be determined.

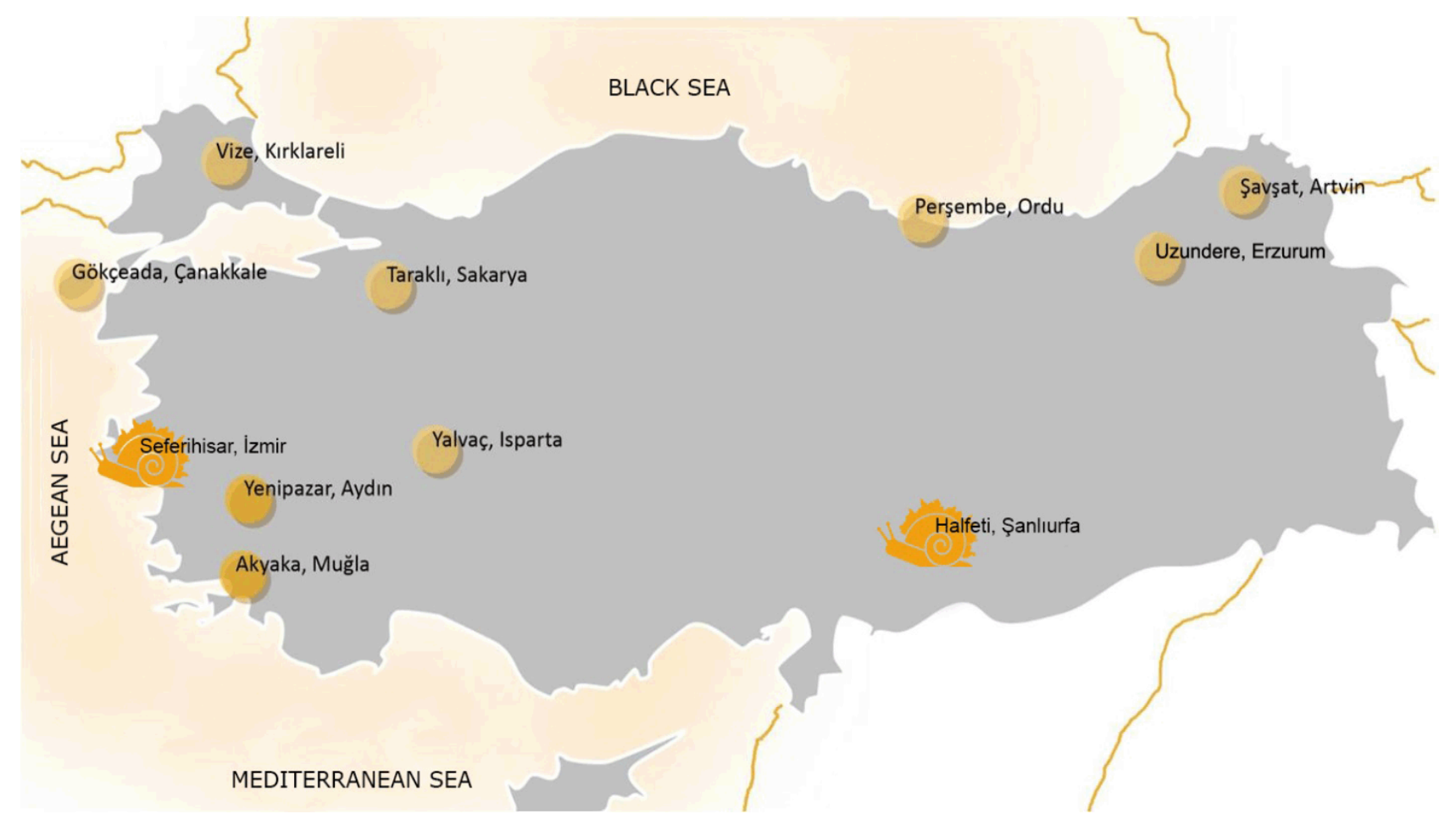

Figure 2. Turkish Cittaslow settlements, Seferihisar and Halfeti 


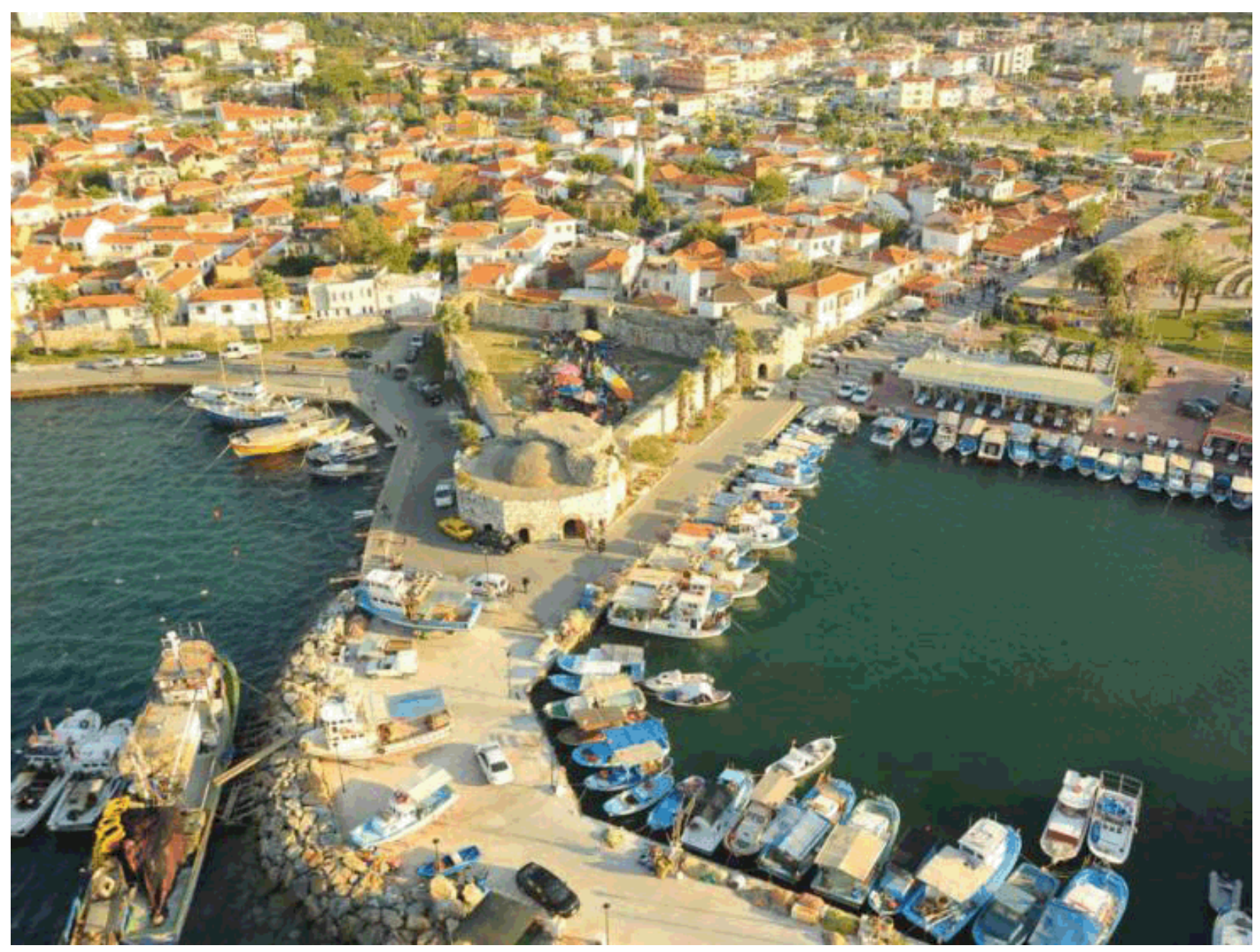

Figure 3. View from Sigacik, Izmir (Retrieved from http://cittaslowturkiye.org/, 2016)

\begin{tabular}{|c|c|c|c|c|c|c|c|c|c|c|}
\hline & \multicolumn{6}{|c|}{ Type of Cultural Heritage } & \multicolumn{3}{|c|}{ Situation of Project } \\
\hline & & \multicolumn{3}{|c|}{ Tangible Heritage } & \multicolumn{3}{|c|}{ Intangible Heritage } & \multirow[b]{2}{*}{ 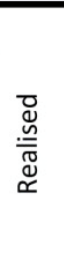 } & \multirow[b]{2}{*}{ 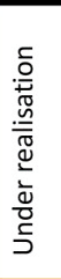 } & \multirow[b]{2}{*}{ 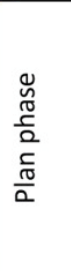 } \\
\hline & & 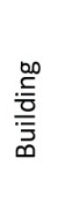 & 劳 & 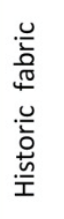 & 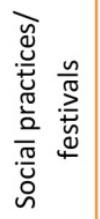 & 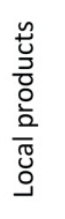 & 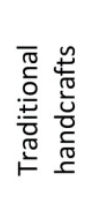 & & & \\
\hline 1 & $\begin{array}{l}\text { Project of "City Memorial Museum of } \\
\text { Seferihisar" }\end{array}$ & $\mathbf{x}$ & & & & & & $\mathbf{x}$ & & \\
\hline 2 & $\begin{array}{l}\text { Conservation Project of Kasım Çelebi } \\
\text { Mosque \& Fatih Madrasah }\end{array}$ & $\mathbf{x}$ & & & & & & & $\mathbf{x}$ & \\
\hline 3 & $\begin{array}{l}\text { Excavation Of Teos City and } \\
\text { Landscaping of the Archeological Area }\end{array}$ & & $\mathbf{x}$ & & & & & & $\mathbf{x}$ & \\
\hline 4 & $\begin{array}{l}\text { Street Improvement of Sigacik Inner } \\
\text { Castle }\end{array}$ & & & $\mathbf{x}$ & & & & $\mathbf{x}$ & & \\
\hline 5 & Meeting day of Seferihisar's Locals & & & & $\mathbf{x}$ & & & $\mathbf{x}$ & & \\
\hline 6 & Festival of Tangerine & & & & $\mathbf{x}$ & $\mathbf{x}$ & & $\mathrm{x}$ & & \\
\hline 7 & Can Yücel Seed Center & & & & & $\mathrm{x}$ & & $\mathbf{x}$ & & \\
\hline 8 & Project of Local Cuisine of Seferihisar & & & & & $x$ & & $\mathbf{x}$ & & \\
\hline 9 & Local Producer's Market & & & & & $\mathbf{x}$ & $\mathbf{x}$ & $\mathbf{x}$ & & \\
\hline
\end{tabular}

Figure 4. Projects that are developed in Seferihisar after the membership to Cittaslow 


\subsection{Effects of Cittaslow Movement on Conservation Cultural Heritage in Seferihisar}

Seferihisar is on the west coast of Izmir. The antique town of Teos is the oldest historical tangible cultural heritage of the settlement where an important part has been recovered and documented. Also, surrounding the town of Seferihisar lies historic buildings, such as hammams, mosques, fountains and housings which date back to the Seljuk and Ottoman era. An important part of these buildings are located in the pattern of Sigacik, a settling surrounded by the fortification walls dated back to the Seljuk era (Figure 3). A section of these buildings belonging to Ottoman and Seljuk periods have been maintained. The cultivation of local agricultural products and local cuisine consist of the settlement's intangible cultural heritage. The local products, which have been produced for centuries by local citizens, have become traditionalized and play a vital role in Seferihisar cuisine.

According to Dogrusoy and Dalgakıran, the reason for Seferihisar' municipality becoming a member of this association was to revive the local economy and increase tourism [17]. In accordance with the vision of the municipality, new conservation projects were developed both for tangible and intangible cultural heritage in Seferihisar. These projects, within the context of the conservation of tangible cultural heritage are developed in building, historic site and fabric scale. Building scaled projects are "Project of City Memorial Museum of Seferihisar" (conservation of the Zenşiye Güler house), "Conservation Project of Kasım Çelebi Mosque and Fatih Madrasah". The site scaled project "Excavation Of Teos City and Landscaping of the Archeological Area" and fabric scaled project is "Street Improvement of Sigacik Inner Castle". Besides, conservation of intangible cultural heritage projects developed as part of social practices are "Meeting day of Seferihisar's Locals" and "Festival of Tangerine". The establishment of "Can Yücel Seed Center", "Project of Local Cuisine of Seferihisar" and "Local Producers' Market Place" are projects that were devised within the local products and traditional handicraft perspective (Figure 4).

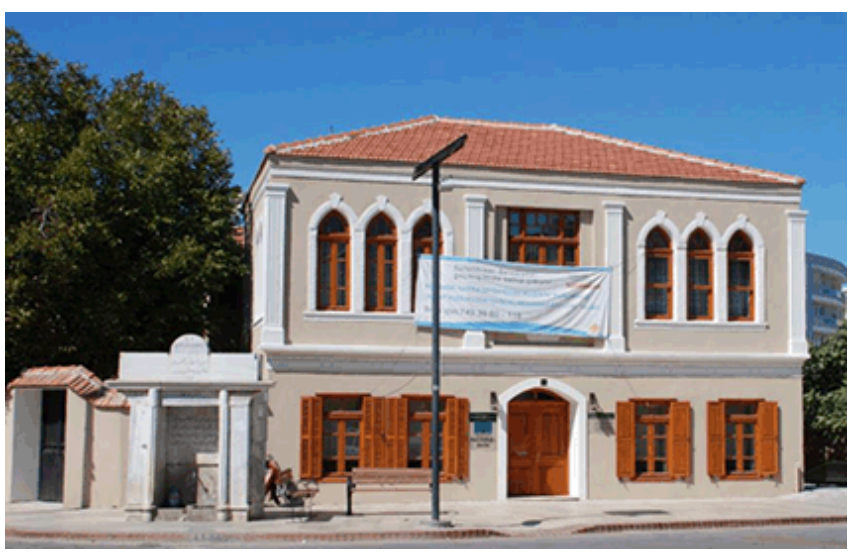

Figure 5. Zensiye Güler House in Seferihisar (Retrieved from Çakar's archieve, 2015)
One of the projects realized performed within building scale is the conservation of Zensiye Guler house to create a Memorial Museum of Seferihisar (Figure 5). The historic building was built in 1929 in Seferihisar center. Today the building is re-used as a memorial museum and a restaurant where local products are served. Historic documents about Seferihisar are exhibited and the local cuisine products are served to the visitors. In this regards, the owner of the estate and the municipality worked jointly.

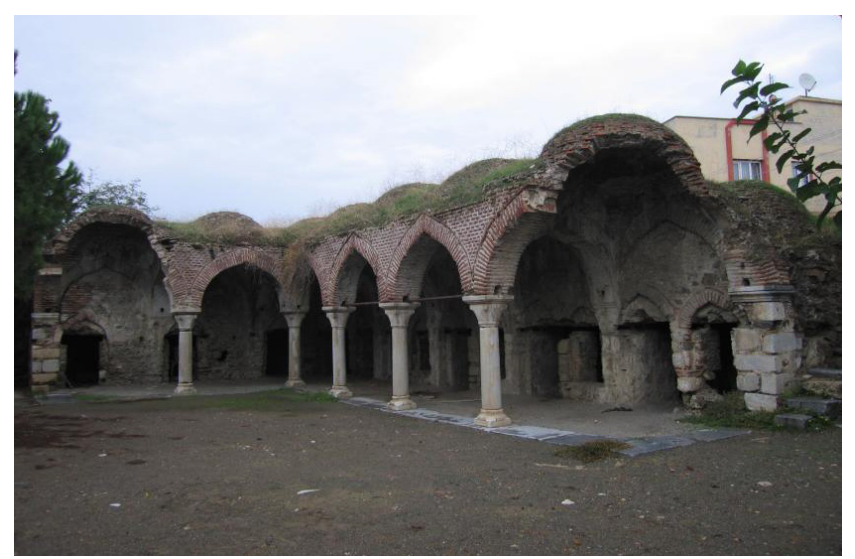

Figure 6. Kasim Celebi Mosque in Seferihisar (Retrieved from N. Kul's archieve, 2016)

Another conservation project developed in building scale is the Conservation Project of Kasım Çelebi Mosque and Fatih Madrasah (Figure 6). Inferentially the madrasah and the mosque were built in 15 th century. Due to a high degree of deterioration, the municipality has begun the works since 2010 for the preservation of the building and accordingly the projects were devised and they were approved. It is planned that the restoration projects will be commenced as soon as the financial support for the conservation works is acquired.

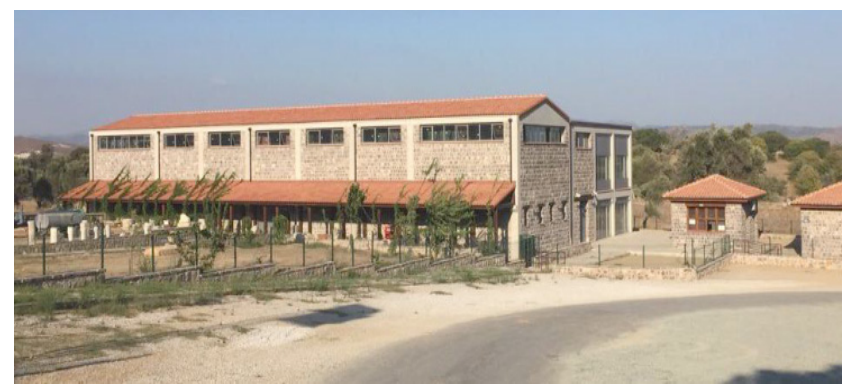

Figure 7. View from Teos Museum (Retrieved from Çakar's archieve, 2015)

One of the greatest contributions of Cittaslow in Seferihisar is Excavation of Teos City and Landscaping of the Archeological Area. In history, because of its geographical location, Teos had become an important commerce and art center [19]. The first excavation in the area began in the 19th century, by the English researchers and periodically continued throughout the years [20]. However, after 1950s, any excavation was realized because of financial difficulties. In 2010, conservation and excavation works 
have restarted again due to increase in funding since the town became more popular after membership to Cittaslow. Conservation and documentation works of various parts were begun. Also, a museum (Figure 7) was built and touring routes were designed within the project of 'Landscaping of the Teos Archeological Site'.

Street Improvement of Sigacik Inner Castle which is a fabric scaled work is the most efficient one in the settlement. The inner castle traditional fabric consists of the dwellings and market buildings constructed of stone, brick and mud brick, mosques, mescids, hammams, shadirvans lining the streets, and small squares. The project, which includes improvement of the facades and streets within the traditional pattern, had realized between 2013 - 2015 through financial supports of local municipality and institutions [21]. Project which aims to integrate the inner castle's housing fabric into town life, can be evaluated positively. However, usage of monotype and inauthentic building materials renders the project questionable from the point of contribution to conservation (Figure 8).

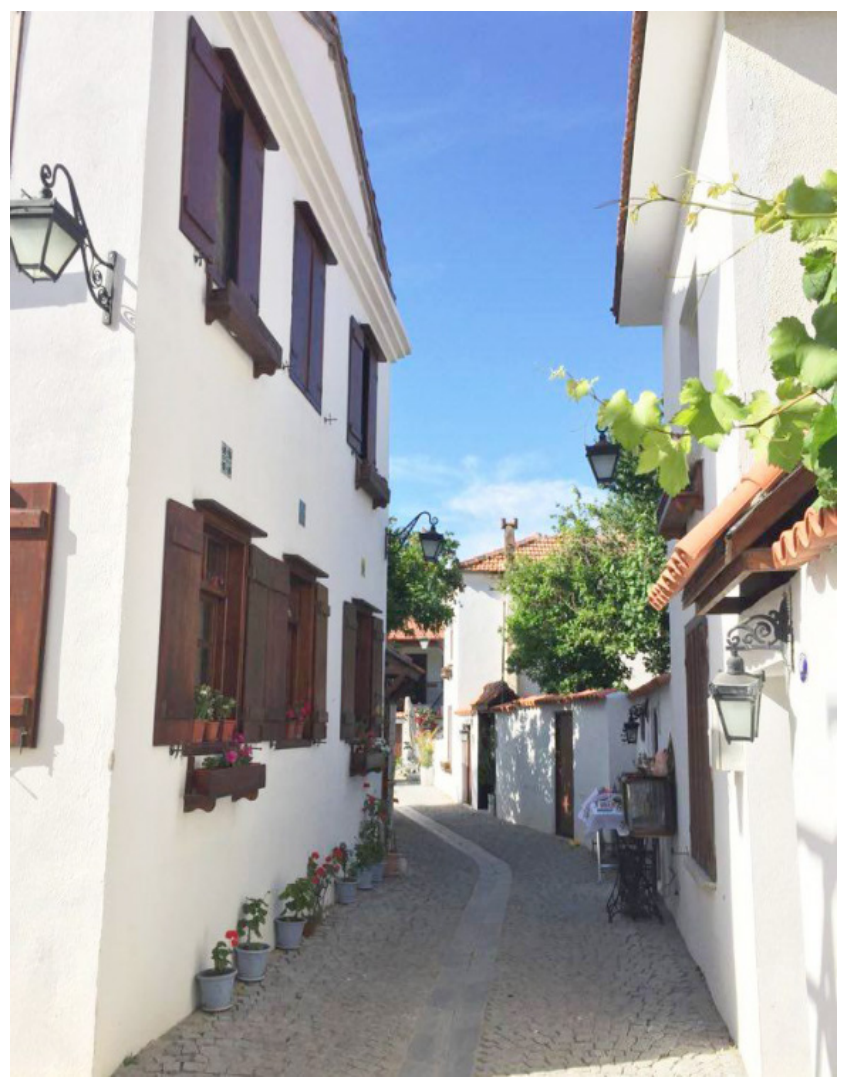

Figure 8. Sigacik Inner Castle (Retrieved from Çakar's archive, 2015)

One of the works has been realized since 2010 within the conservation of the intangible cultural heritage, is the project of Meeting Day of Seferihisar's Locals. The goal of the festival that utilizes the logo of Cittaslow is to introduce traditions and local values by organizing events [22]. Another event is Mandarin Festival which has been realized since 2009 to support the producers, encouraging the cultivation of mandarin and introduction of it. In this regards, several events are organized by the municipality and attendance of local people and visitors is achieved.

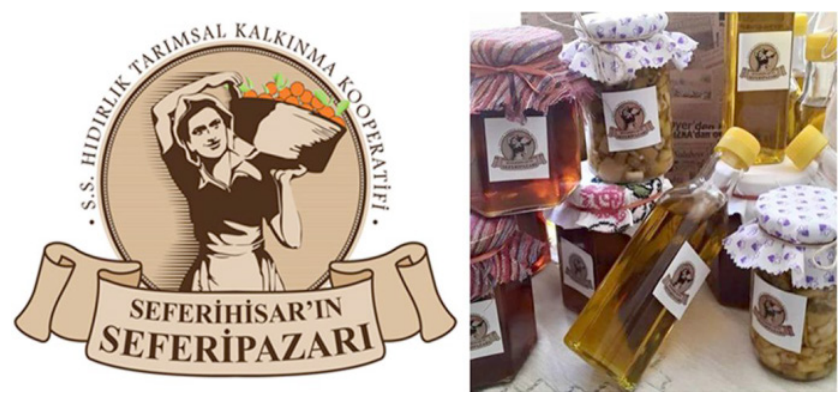

Figure 9. Local products of Seferihisar (Retrieved from $\mathrm{http}: / /$ seferipazar.com/)

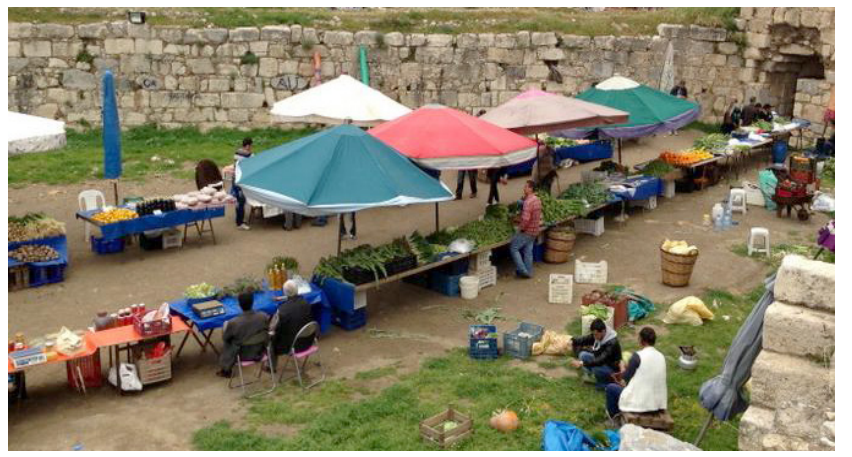

Figure 10. Local Producer Market in Sigacik (Retrieved from Çakar's archive, 2015)

Can Yücel Seed Center' project that focuses on the conservation of local products is an organization that has begun in 2011 by the contributions of municipality (Figure 9). With this center, local people are encouraged to use local seeds thus it prevented extinction of those products and several educational trainings are performed [19]. Another project to sustain local products is the Local Producer's Market that was established in 2009 (Figure 10). Within this market, which is located periodically in Sigacik Inner Castle, only traditional goods produced by the locals can be sold. Local products are not packaged using branded packaging thus attracting the visitor's attention and encouraging the continuation of production. It also contributes greatly to the local economy. Seferihisar's Traditional Cuisine, which is organized by the municipality and other various civil organizations, is another project for conserving and gaining recognition the local cuisine. The goal of this project, which is based on the Slow Food Philosophy, is to develop local cuisine into a brand name and supply it to the consumers online [23].

\subsection{Effects of Cittaslow Movement on Conservation Cultural Heritage in Halfeti}

Halfeti is a town located in the province of Şanlıurfa and is situated along the River Firat. Halfeti was a trade point where green areas and small scaled commercial buildings are 
located in coastline and large scaled public buildings are located in inner part of the town [24]. The built heritage of Halfeti is consisted of traditional housings constructed with local materials situated in courtyards, historical mosques, churches, hammams, mescids, mausoleums and khans. Its intangible cultural heritage is comprised of local cuisine, the tradition of Sira night, local music, clothes, traditional handicraft as well as local black rose cultivation [25].

In 2000, when the Birecik Barrage, in regards of GAP (The Southern Anatolian Project), went operational, a large part of Halfeti became flooded (Figure 11). Due to the flooding, a great majority of buildings were faced with the threat of destruction and the negative effects that occurred in this environment caused great discussions. Moreover, the local citizens who had lost their habitats were forced to relocate to another village outside of Halfeti called Karaotlak [25]. The local citizens, who had to evacuate their traditionally built dwellings, upon return to the New Halfeti, were placed in uniform monotype and non-identifiable concrete buildings, furthering them from their traditional lifestyles. This situation not only damaged town's historical fabric, but also its intangible assets. The important areas, which were flooded and contained these valuable cultural heritages and the harm that was inflicted upon them brought a host of criticism and sparked great debate on how to preserve these heritages better. Today, the historical area that is submerged and known as Old Halfeti is planned to be rescued to conserve its cultural heritage and its touristic value.

After this unfortunate circumstance, rescuing these areas to be submerged and reviving Halfeti's historical centre back into a livable environment has been an important subject for the municipality. The municipality's approach to the conservation of traditional values and Halfeti's rich tangible and intangible cultural heritage were an important factor for the town being a member of the Cittaslow association. By meeting the necessary conditions, Halfeti's membership was achieved in 2013.

The necessity of maintaining the conservation by preventing the extinction of the area flooded in Halfeti and redesigning the town life that became extraordinary makes it compulsory to make policies to protect the tangible cultural heritage previously. It is for this reason that Halfeti is different from other Cittaslow towns. Building scaled "Resurface Project of Ulu Mosque and Landscaping" and fabric scaled "Project of Improvement of Coastline of Halfeti Urban Site Area", "Project of Improvement of Savasan Village" and "Project of Street Improvement of Old Halfeti (Atatürk and Orta Street)" are works that are developed after the membership of the town to Cittaslow movement (Figure 12).

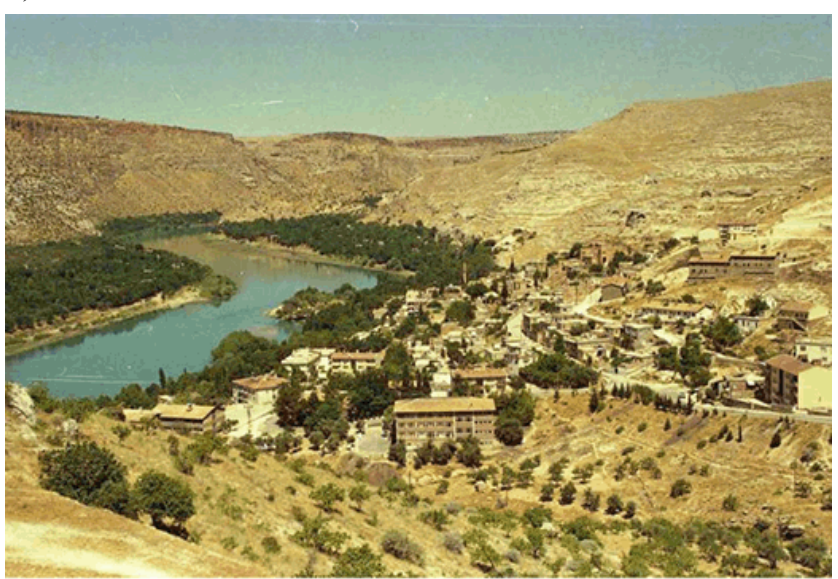

View from Halfeti in 2000 before the construction of Birecik barrage

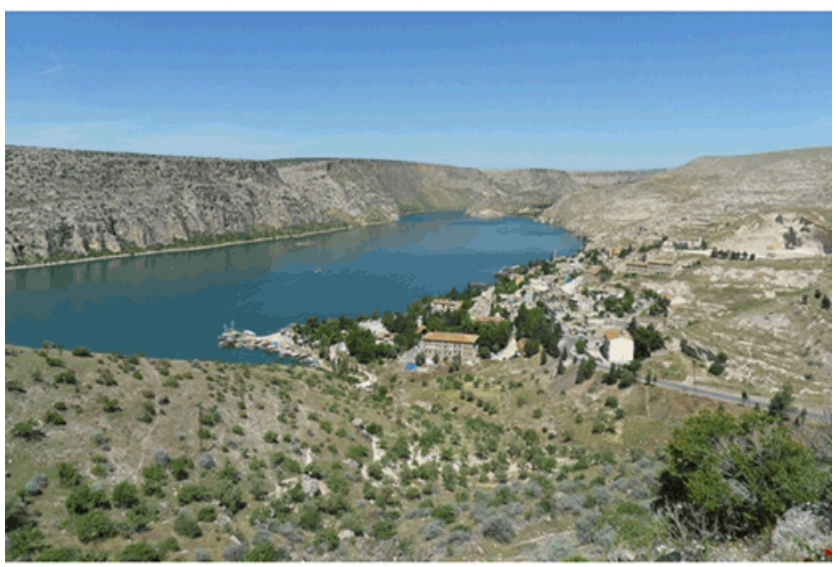

View from Halfeti in 2010 after the construction of Birecik barrage

Figure 11. View of Halfeti before-after the construction of the barrage (Retrieved from M. Topalan, 2016) 


\begin{tabular}{|c|c|c|c|c|c|c|c|c|c|c|}
\hline & \multicolumn{6}{|c|}{ Type of Cultural Heritage } & \multicolumn{3}{|c|}{ Situation of Project } \\
\hline & & \multicolumn{3}{|c|}{ Tangible Heritage } & \multicolumn{3}{|c|}{ Intangible Heritage } & \multirow{3}{*}{ 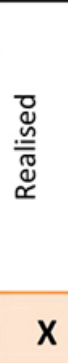 } & \multirow[b]{2}{*}{ 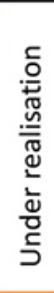 } & \multirow[b]{2}{*}{ 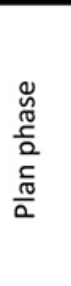 } \\
\hline & & 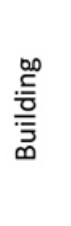 & 葍 & 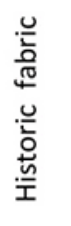 & 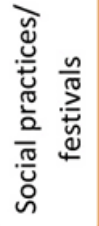 & 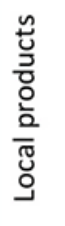 & 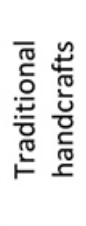 & & & \\
\hline 1 & $\begin{array}{l}\text { Resurface Project of Ulu Mosque and } \\
\text { Landscaping }\end{array}$ & $\mathbf{x}$ & & & & & & & & \\
\hline 2 & Improvement of Savasan Village & & & $x$ & & & & & & $\mathbf{x}$ \\
\hline 3 & $\begin{array}{l}\text { Project of Street Improvement of Halfeti } \\
\text { (Atatürk \& Orta Street) }\end{array}$ & & & $\mathbf{x}$ & & & & & & $x$ \\
\hline 4 & $\begin{array}{l}\text { Project of Improvement of Coastline of } \\
\text { Halfeti Urban Site Area }\end{array}$ & & $x$ & & & & & $\mathbf{x}$ & & \\
\hline 5 & Local Black Rose Festival & & & & & $\mathbf{x}$ & & & & $\mathrm{x}$ \\
\hline
\end{tabular}

Figure 12. Projects that are developed in Halfeti after the membership to Cittaslow

Resurface Project of Ulu Mosque and Landscaping in building scale is developed and will be implemented and come to realize soon. In 2000, during the construction of the Birecik Barrage, the mosque was partially left under water (Figure 13). A conservation project was prepared for conservation against corrosions of the water and the local committee of conservation approved it. According to the project, it was decided that the mosque would be rebuilt by raising it from its original place. This project, which has not been implemented as of yet, is a joint project of the Ministries and the Directorate General of Foundations.

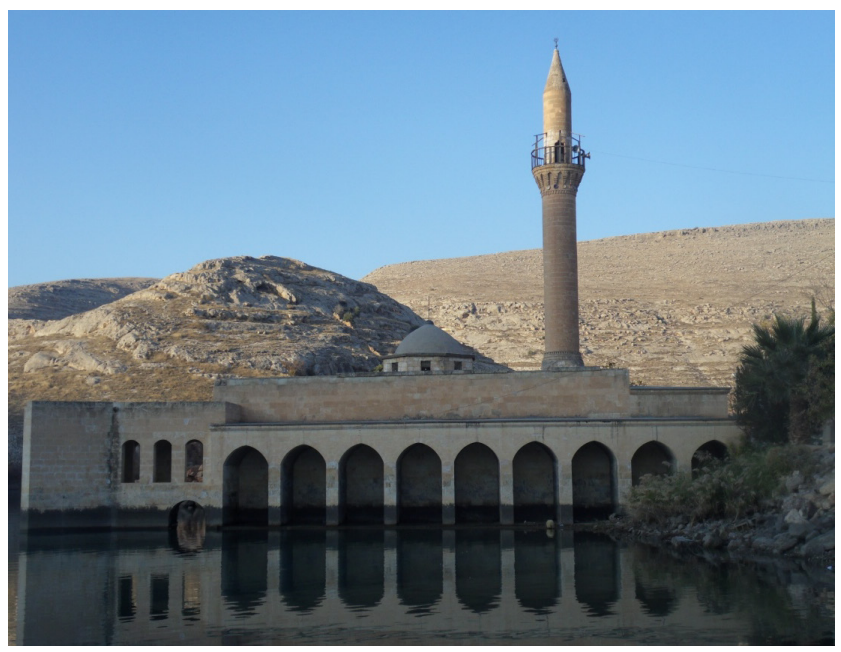

Figure 13. View from Ulu Mosque (Retrieved from M. Topalan, 2016)

Another project is Project of Improvement of Coastline of Halfeti Urban Site Area. After the flood of Halfeti, reconstruction of the riverside was imperative to make it habitable again for locals and also visitors. In this work, several arrangements were made on the east side of the river. On the west side, a suspended wooden bridge has been built for pedestrians. Also, new buildings have been built for the visitors and a floating pier was constructed along the riverside on the part of Old Halfeti for boats to berth. The project was realized under the leadership of the municipality and with the financial support of a local development agency between the years $2013-2014$.

Project of Improvement of Savasan Village, is a project which will be implemented on fabric scale. Savasan is a small-scaled village of Halfeti where the transportation is provided by the river-way. The pattern of houses, which is about to disappear due to abandonment, is similar to Halfeti with their construction techniques and material (Figure 14). Today, nearly half of the traditional housing and the agricultural areas are all mostly submerged in water. After membership to Cittaslow, in 2013, the village was accepted as an urban site area and some of the buildings were registered. In the future, it projects of conservation of the area and street improvement has planned. The developed works, are being undertaken by the Şanlıurfa Cultural and Tourism Administration.

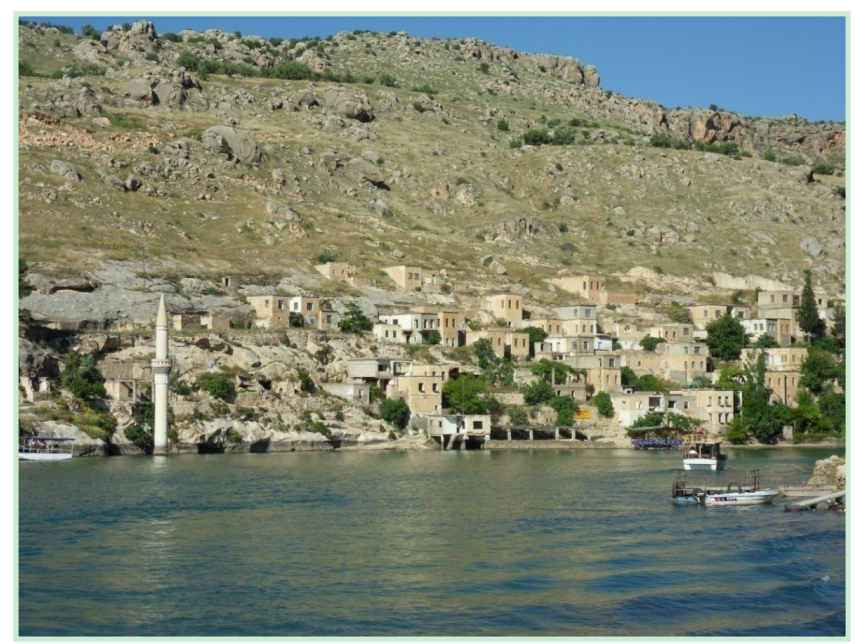

Figure 14. View from Savasan Village (Retrieved from M. Topalan, 2016) 
Another project on fabric scale, which is under preparation, is the Project of Street Improvement of Old Halfeti (Atatürk and Orta Street). Improvements of facades of historical buildings are planned within this project. The project is undertaken by the Şanllurfa Culture and Tourism Administration and it is expected to begin in 2017.

After the membership to Cittaslow, any conservation of intangible heritage project has been performed in Halfeti yet. However, plans for the cultivation of a black rose that is a product typical of Halfeti have been made for the future. In regard to this, after 2013, to encourage and popularize the cultivation of the black rose, trainings were performed and greenhouses were set up in the appropriate locations under the Local Black Rose Festival.

\section{Discussion}

In this study, the examination of effects of the conservation based projects developed in Seferihisar and Halfeti after becoming a Cittaslow is done. These projects were examined under title of tangible and intangible cultural heritages.

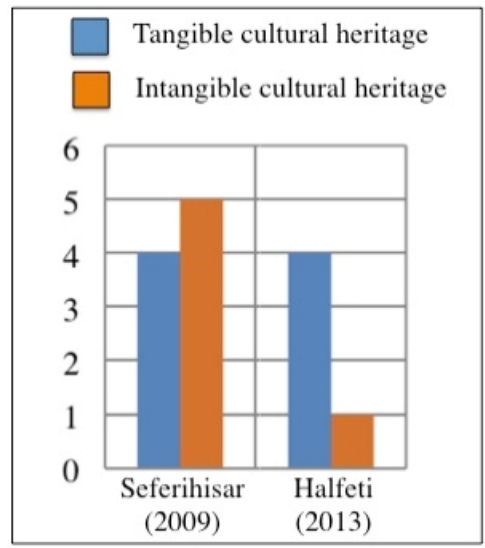

Figure 15. Tangible and intangible cultural heritage projects in Seferihisar and Halfeti

When projects of two settlements are compared, it has been observed that while especially in Seferihisar, the focus is on the conservation of the local products therefore the projects, which were mostly directed on the conservation of intangible cultural heritage were developed. On the other hand, projects developed in Halfeti show that no extensive work has been done in this field so far (Figure 15). However, in respect of the conservation of tangible cultural heritage, it is determined that in both counties, several projects were developed in respect of building, fabric and site scales. But in Halfeti, as it became a member recently, the quantity of the projects is less than the other's. In this regards, while projects developed in Seferihisar are aimed at creating a trade-mark value, in Halfeti the main goal is to rescue the flooded historical area.

Nowadays, when comparing the projects that were completed and under planning; in Seferihisar 7 projects out of 9 have been completed, 2 of which are in the process of being implemented. Whereas in Halfeti, 2 projects out of 5 have been completed and 3 are in the planning stages. The reason for some of the projects not being able to pass to the implementation stage is because during the stage of candidacy and while observing the process of developing an active project in the first year of membership, these works, in the long run lost their sustainability. From this point of view, in these works, preparing the projects, implementation and the transfer of funds to be continuous is very important.

When evaluating the quality of developed projects in Seferihisar, it can be observed that the underlying aim is to popularize and brand the town's name. In this regard, an increment is observed in project that focuses on the conservation of intangible cultural heritage. As a result, it can be said that the effects of these projects are disproportionate augmentation of tourism and the efforts for creating an artificial local trademark. These effects demonstrate that projects have caused a trade-mark for the town instead of the conservation of local identity, which conflicted with the philosophy of the Association.

As for Halfeti, the town that began to lose its authenticity, projects were developed to conserve the traditional pattern of the town. On the other hand, projects within the scope of revitalization of Halfeti's intangible heritage and redevelopment of its identity are in plan phase.

\begin{tabular}{|c|c|}
\hline \multicolumn{2}{|r|}{ Seferihisar } \\
\hline \multirow{4}{*}{ Positive } & Recognition of the cultural potential of the settlement. \\
\hline & $\begin{array}{c}\text { Encouragement of the conservation of local products and } \\
\text { usage of traditional places. }\end{array}$ \\
\hline & Becoming a popular "Slow" destination. \\
\hline & Increment of financial supports. \\
\hline \multirow{4}{*}{ Negative } & Creation of artificial cultural events. \\
\hline & Impermanent conservation projects. \\
\hline & Development of tourism focused projects. \\
\hline & Increment of visitors. \\
\hline \multicolumn{2}{|r|}{ Halfeti } \\
\hline \multirow{4}{*}{ Positive } & Recognition of the cultural potential of the settlement. \\
\hline & Becoming a popular "Slow" destination. \\
\hline & Increment of financial supports. \\
\hline & $\begin{array}{l}\text { Speedup of bureaucratic processes related to conservation } \\
\text { projects. }\end{array}$ \\
\hline \multirow{2}{*}{ Negative } & Impermanent conservation projects. \\
\hline & Development of tourism focused projects. \\
\hline
\end{tabular}

Figure 16. Effects of Cittaslow on conservation cultural heritage in Seferihisar and Halfeti

In considerations of searches, it can be said that the projects developed under the association had direct and indirect effects on the conservation policies of both of the cities (Figure 16). The most important and positive effect of the introduction of Cittaslow philosophy on both of the towns determine the cultural potentials of the towns which guided the projects to be developed in this manner. By this, 
especially in Seferihisar, the production of local products in traditional places is encouraged and a traditional pattern is gained throughout the town. Also, the pioneer approach of the municipality in conservation of the cultural heritage can be considered as a direct effect. At the same time, this situation speed up the bureaucratic processes in regard to conservation.

It could be said that another positive and indirect effect is that, by giving a settlement a status such as 'slow', bring it recognition by gaining a brand name for itself. Especially in Seferihisar upon increase in popularity brought the increase of financial support.

The negative effect that the Cittaslow movement has had especially on Seferihisar is that an artificial cultural development has been created by projects of local festivals. Even if these projects have been created to revive cultural values, it paved way to a fictitious town identity. Another negative effect is that the projects developed in the first stage of the towns' membership were not provided with sustainability.

One other negative and indirect effect, which was created by the municipality due to the misinterpretation of Cittaslow by the municipality, is that the usage of the title of the association for touristic purposes instead of internalizing the philosophy of slowness. As a result of this, the quantity of visitors to the town increased in such numbers that it conflicted with the Cittaslow philosophy.

\section{Conclusions}

The Cittaslow movement's fundamental approach is that the less populated settlements should, in all aspects bring out its own potential by bringing the needs of the era to the town and its community, an increase in the quality of urban living, cultural values and differences, being in the forefront. Although the movement functioning in this direction is not the first goal, the conservation of cultural heritage in totality is regarded with the utmost importance.

The membership of Seferihisar and Halfeti to Cittaslow has provided a prominence of local potentials of these towns under the guidance of municipalities. However, the misappropriation of the philosophy of Cittaslow in some ways, such as the creation of an inauthentic identity for tourism intentional, has produced some results conflicting with the philosophy of the association.

As a result, the inclusion of the towns of Seferihisar and Halfeti into the association as members brought awareness and in turn an important stage has been taken for the necessity to conserve cultural heritage in an integrated method. In order for this stage to create positive outcomes, a balance between the conservation of the identities of settlements and the development of high-quality living areas must be provided. In the case that this balance is integrated into all the aspects of the urban area, it can be said that Cittaslow movement can be considered as a new approach which contributes positively to the integrative conservation of the cultural heritage.

\section{Acknowledgements}

This article is prepared in the context of the master thesis with the title of "Cittaslow Movement in the Context of Conservation of Cultural Heritage: Case of Turkey" studied in Dokuz Eylul University, Graduate School of Natural and Applied Sciences, Architecture Department.

\section{REFERENCES}

[1] M. Vecco. A Definition of Cultural Heritage: From the Tangible to Intangible, Journal of Cultural Heritage, Science direct, Vol. 11, 321-324

[2] M. Miele. Cittaslow Producing Slowness Against the Fast Life, Space and Policy, 12(1), 135-156, 2008.

[3] D.U. Binan, B. Cantimur. Koruma Alanında Somut ve Somut Olmayan Boyutlarıyla Miras Kavramının Gelişimi ve "Yerin Ruhu”, Mimari Korumada Güncel Konular, 175-191.

[4] UNESCO Convention for the Protection of Cultural Property in the Event of Armed Conflict with Regulations for the Execution of the Convention, Online available from http://portal.unesco.org/

[5] ICOMOS The Venice Charter, Online available from https://www.icomos.org/

[6] UNESCO Convention Concerning the Protection of the World Cultural and Natural Heritage, Online available from http://whc.unesco.org/

[7] ICOMOS The Amsterdam Declaration, Online available from http://www.icomos.org/

[8] ICOMOS Deschambault Charter for the Preservation of Quebec's Heritage, Online available from https://www.icomos.org/

[9] ICOMOS Washington Charter on the conservation of Historic Towns na Urban Areas, Online available from http://www.icomos.org/

[10] UNESCO Popular and Traditional Cultural Protection Recommendation, Online available from http://portal.unesco.org/

[11] UNESCO The Nara Document on Authenticity, Online available from whc.unesco.org/

[12] UNESCO Burra Charter, Online available from http://australia.icomos.org

[13] UNESCO Safeguarding of The Tangible Cultural Heritage, Online available from http://www.unesco.org

[14] UNESCO Yamato Declaration on Integrated Approaches for Safeguarding Tangible and Intangible Cultural Heritage, Online available from http://portal.unesco.org

[15] ICOMOS Charter of Quebec, Online available from 
http://whc.unesco.org/

[16] C. Honoré. In Praise of Slowness, Harperone Press, California, 2004.

[17] I. T. Doğrusoy, A. Dalgakıran. An Alternative Approach In Sustainable Planning: Slow Urbanism, International Journal of Architectural Research, Vol. 5 (1), 127-142.

[18] Cittaslow Uluslararası Organizasyonu, Online available from http://cittaslowturkiye.org/

[19] A. N. Atilla, N. Öztüre. Seferihisar Teos’tan Sakin Bir Şehre. Öztüre Kültür Press, Izmir, 2011.

[20] M. Kadioglu. Teos Rehber Kitap. Ankara University, Ankara, 2012.
[21] Municipality of Seferihisar, Sigacik'a altın dokunuş, Online available from http://seferihisar.bel.tr/

[22] Municioality of Seferihisar, Seferihisarlılar Bulusmas1 Başliyor, Online available from http://seferihisar.bel.tr/

[23] Seferipazar, Seferihisar'in Geleneksel Mutfağı Projesi, Online available from $\mathrm{http}: / /$ seferipazar.com

[24] M. Bakirci, Turkiye'de Baraj Yapimi Nedeniyle Yer Degiştiren Bir Sehir "Halfeti”, Journal of Cografya, Vol. 10, 55-78.

[25] M. Topalan. The Typologies of Plan, Facade and Structural Elements of Traditional Halfeti Houses, Master Thesis in University of Dicle in Institute of Science, Diyarbakır, 2016.

[26] Figure 1, 2, 4, 12, 15, 16 are prepared by authors. 